Pesq. Vet. Bras. 30(4):305-310, abril 2010

\title{
Effect of Bone Morphogenetic Protein-7 (BMP-7) on in vitro survival of caprine preantral follicles ${ }^{1}$
}

\author{
Valdevane R. Araújo ${ }^{2}$, Cleidson M. Gomes da Silva², Deborah M. \\ Magalhães ${ }^{2}$, Gerlane Modesto da Silva², Sônia N. Báo ${ }^{3}$, José Roberto Viana \\ Silva ${ }^{4}$, José Ricardo de Figueiredo ${ }^{2}$ and Ana Paula R. Rodrigues ${ }^{2}$
}

\begin{abstract}
Araújo V.R., Silva C.M.G., Magalhães D.M., Silva G.M., Báo S.N., Silva J.R.V., Figueiredo J.R. \& Rodrigues A.P.R. 2010. Effect of Bone Morphogenetic Protein7 (BMP-7) on in vitro survival of caprine preantral follicles. Pesquisa Veterinária Brasileira 30(4):305-310. Programa de Pós-Graduação em Ciências Veterinárias, Laboratório de Manipulação de Oócitos e Folículos Pré-Antrais, Universidade Estadual do Ceará, Av. Paranjana 1700, Campus do Itaperi, Fortaleza, CE 60740-000, Brazil. Email: val_exclusiva@yahoo.com.br

This study was conducted in order to verify the effect of different concentrations of BMP-7 in the in vitro survival and development of caprine preantral follicles. Fragments of caprine ovarian cortical tissue were cultured for 1 or 7 days in Minimum Essential Medium $\left(\mathrm{MEM}^{+}\right)$supplemented with different concentrations of BMP-7 $(1,10,50$ or $100 \mathrm{ng} / \mathrm{ml})$. Noncultured fragments or those cultured for 1 or 7 days were processed for classical histology and transmission electron microscopy (TEM). Parameters such as follicular survival, activation and growth were evaluated. The results showed that, after 1 or 7 days of culture, the percentage of morphologically normal follicles was significantly reduced in all treatments when compared with fresh control, except at $1 \mathrm{ng} / \mathrm{ml}$ of BMP-7 for 1 day. In addition, the concentration of $10 \mathrm{ng} / \mathrm{ml}$ of BMP-7 significantly increases follicular diameter from day 1 to 7 of culture. There was no influence of the other concentrations of BMP-7 regarding to the follicular and oocyte diameter. Ultrastructure studies confirmed follicular integrity after 7 days of culture in 1ng/ml BMP-7. In conclusion, small concentrations of BMP-7 can improve the survival and growth of caprine preantral follicles during in vitro culture.
\end{abstract}

INDEX TERMS: Ovary, preantral follicles, growth factor, bone morphogenetic protein-7, BMP-7, goats.

RESUMO.- [Efeito da Proteína Morfogenética Óssea 7 (BMP-7) para a sobrevivência in vitro de folículos préantrais caprinos.] $O$ presente trabalho foi conduzido de modo a se verificar o efeito de diferentes concentrações da

\footnotetext{
${ }^{1}$ Received on September 23, 2008.

Accepted for publication on October 29, 2009.

2 Programa de Pós-Graduação em Ciências Veterinárias (PPGCV), Laboratório de Manipulação de Oócitos e Folículos Pré-Antrais (Lamofopa), Universidade Estadual do Ceará (UECE), Av. Paranjana 1700, Campus do Itaperi, Fortaleza, CE 60740-000, Brazil. *Corresponding author: val_exclusiva@yahoo.com.br

${ }^{3}$ Laboratório de Microscopia Eletrônica, Departamento de Biologia Celular, Instituto de Ciências Biológicas, Universidade de Brasília, 70919970 Brasilia, DF, Brazil.

${ }^{4}$ Núcleo de Biotecnologia de Sobral (Nubis), Faculdade de Medicina de Sobral, Universidade Federal do Ceará, Av. Geraldo Rangel 100/ 186, Sobral, CE 60041-040, Brazil.
}

BMP-7 no desenvolvimento in vitro de folículos pré-antrais caprinos. Fragmentos de tecido cortical ovariano caprino foram cultivados por 1 ou 7 dias em Minimum Essential Medium $\left(\mathrm{MEM}^{+}\right)$suplementado com diferentes concentrações de BMP-7 (1, 10, 50 ou $100 \mathrm{ng} / \mathrm{ml})$. Os fragmentos não cultivados ou aqueles cultivados por 1 ou 7 dias foram processados para histologia clássica e microscopia eletrônica de transmissão (TEM), sendo avaliados parâmetros morfológicos indicativos de viabilidade, ativação e crescimento. Os resultados mostraram que o percentual de folículos morfologicamente normais diminuiu significativamente em todos os tratamentos quando comparados ao controle, exceto na concentração de $1 \mathrm{ng} / \mathrm{ml}$ por 1 dia de cultivo. Já no $D 7$ todos os tratamentos reduziram significativamente os percentuais de folículos morfologicamente normais. Utilizando $10 \mathrm{ng} / \mathrm{ml}$ de BMP-7 foi observado um 
aumento significativo no diâmetro folicular quando comparados os diferentes períodos de cultivo. Não houve influência das demais concentrações de BMP-7 quando avaliados além do diâmetro folicular o diâmetro oocitário. A análise por TEM confirmou a integridade ultra-estrutural nos folículos após 7 dias de cultivo com $1 \mathrm{ng} / \mathrm{ml}$ de BMP-7 . Em conclusão, o BMP-7 em baixas concentrações pode meIhorar a sobrevivência e o crescimento durante o cultivo in vitro de folículos pré-antrais caprinos.

TERMOS DE INDEXAÇÃO: Ovário, folículos pré-antrais, fator de crescimento, proteína morfogenética óssea 7, BMP-7, caprinos.

\section{INTRODUCTION}

The regulation of folliculogenesis in the mammalian ovary is a complex process and is controlled by both extraovarian factors, e.g. pituitary gonadotropins, and locally produced paracrine factors (Gougeon 1996). Whereas the later stages of gonadotropin-dependent follicle growth have been more thoroughly studied, the early stages of folliculogenesis, especially the initiation of follicle growth, remain enigmatic (Danforth et al. 2003). Accumulated evidence during the past decade suggests that the initiation of folliculogenesis is a continuous process regulated by a variety of endocrine and intra-ovarian factors. One of these factors is the bone morphogenetic protein (BMP), which is a member of transforming growth factor-b (TGF-b) superfamily, representing a specific subfamily. Until now, 15 BMPs were described, and only seven (BMP-2, -3, -3b, -4, -6, -7 e -15) localized in mammalian ovaries (Hogan 1996, Dube et al. 1998, Wozney \& Rosen 1998). These proteins are extracellular molecules involved in the regulation of growth, differentiation and apoptosis of several cellular types, besides playing a role in folliculogenesis and ovulation (Glister et al. 2004).

Studies using the technique of in situ hibridization demonstrated the presence of the mRNA of BMP-7 in theca cells of rat preovulatory follicles (Shimasaki et al. 1999) and in pituitary cells of transgenic mouse (Huang et al. 2001). BMP acts by BMPR-IA, -IB and II receptors, which were indentified and localized in different structures of swine ovary, such as oocyte, granulosa and luteal cells and blood vessels (Quinn et al. 2004). The mRNAs for BMP receptors (BMPR-IA, -IB, and II) are expressed in oocytes and granulosa cells of goat ovarian follicles at all stages of development (Silva et al. 2004a) as well as in follicles of other mammalian species (murine: Erickson et al. 2003; ovine: McNatty et al. 2005; bovine: Glister et al. 2002). Other studies performed with rats demonstrated that BMP-7 receptors are expressed in granulosa cells of follicles from the secondary stages onward, also showing that this protein is expressed in theca cells (Shimasaki et al. 1999).

In mouse, in vitro studies demonstrated that BMP-7 is involved in the control of oocyte growth, granulosa cells proliferation (Lee et al. 2001), as well as in the transition from primordial to primary follicular stage (Lee et al. 2004). Besides these previous information about BMP-7, the action of these proteins in the mammalian reproduction is still litlle known. Moreover, no evidence of BMP-7 action on the germinative cells was verified in the caprine specie. Thus, the aim of the present study was to evaluate the effect of different concentrations of BMP-7 on the in vitro survival and development of caprine preantral follicles.

\section{MATERIALS AND METHODS}

Unless mentioned otherwise, the culture media, recombinant human BMP-7 and other chemicals used in the present study were purchased from Sigma Chemical Co. (St Louis, MO).

Source of ovaries. Ovarian cortical tissues were obtained from five cross-breed goats $(n=5)$ collected at a local slaughterhouse. Immediately postmortem, the ovaries were washed in $70 \%$ alcohol for 10 seconds following two times in

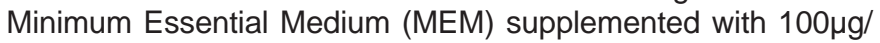
$\mathrm{ml}$ penicillin and $100 \mu \mathrm{g} / \mathrm{ml}$ streptomycin. The pairs of ovaries were transported within 1 hour to the laboratory in MEM at $4^{\circ} \mathrm{C}$ (Chaves et al. 2008).

Experimental protocol. The culture system was described in detail earlier by our team (Silva et al. 2004b, Matos et al. 2007a). Ovarian cortical tissue from the same ovarian pair was cut in 11 slices $(3 \mathrm{~mm} \times 3 \mathrm{~mm} \times 1 \mathrm{~mm})$ using a scissor and scalpel under sterile conditions. The tissue pieces were then either directly fixed for histological and ultrastructural analysis (fresh tissue, control) or placed in culture for 1 or 7 days. Caprine tissues were transferred to 24-well culture dishes containing $1 \mathrm{ml}$ of culture media. Culture was performed at $39^{\circ} \mathrm{C}$ in $5 \% \mathrm{CO}_{2}$ in a humidified incubator. The basic culture medium consisted of MEM ( $\mathrm{pH} 7.2-$ 7.4) supplemented with ITS $(10 \mu \mathrm{g} / \mathrm{ml}$ insulin, $5.5 \mu \mathrm{g} / \mathrm{ml}$ transferrin, and $5 \mathrm{ng} / \mathrm{ml}$ selenium), $0.23 \mathrm{mM}$ pyruvate, $2 \mathrm{mM}$ glutamine, $2 \mathrm{mM}$ hypoxantine, $1.25 \mathrm{mg} / \mathrm{ml}$ of bovine serum albumin (BSA). To test the effects of BMP-7, different concentrations $(0,1,10,50$ or $100 \mathrm{ng} / \mathrm{ml}$ ) of this factor were added to the culture medium. Each treatment was repeated five times and the culture media was replenished every other day.

Morphological analysis and assessment of in vitro follicular growth. Before culture (fresh control) and after one or seven days in culture, all the pieces were fixed in Carnoy solution for $12 \mathrm{~h}$ and then dehydrated in increasing concentrations of ethanol. After paraffin (Synth, São Paulo, Brazil) embedding, the caprine tissues pieces were cut into $7 \mu \mathrm{m}$ sections and stained by Periodic Acid Schiff - hematoxylin. Follicle stage and survival were assessed microscopically on serial sections. Coded anonymized slides were examined under a light microscope (Nikon, Japan) at 400x magnification.

The follicles were classified as described by Hulshof et al. (1994) in primordial (one layer of flattened granulosa cells around the oocyte), or growing follicles i.e., primary (a single layer of cuboidal granulosa cells around the oocyte), or secondary (oocyte surrounded by two or more layers of cuboidal granulosa cells). These follicles were classified individually as histologically normal when an intact oocyte was present, i.e. an oocyte without a pyknotic nucleus or cytoplasmic retraction, surrounded by granulosa cells, which are well organized in one or more layers and that have no pyknotic nucleus. Atretic follicles were defined as those with a retracted oocyte, pyknotic nucleus, and/or disorganized granulosa cells detached from the basement membrane. Overall, 150 follicles were evaluated for each treatment $(30$ follicles per treatment in one repetition $x 5$ repetitions $=150$ follicles).

The percentages of healthy primordial and developing follicles were calculated before (fresh control) and after culture 
in each medium. In addition, follicle and oocyte diameters were measured only in healthy follicles. Follicle diameter was recorded from edge to edge of granulosa cell membrane, or from the outside edge of the theca cell layer when present. Oocyte diameter was recorded from edge to edge of the oocyte membrane. Two perpendicular diameters were recorded for each and the average of these two values was reported as follicle and oocyte diameters, respectively. Care was taken to count each follicle only once as we have also done in our earlier studies (Matos et al. 2007b).

Ultrastructural analysis of caprine preantral follicles. For better evaluation of the follicular morphology, ultrastructural studies were carried out on fragments of fresh control and treatments that maintained follicular morphology during the histological analysis. Small pieces $\left(1 \mathrm{~mm}^{3}\right)$ of caprine ovarian tissues were fixed in $2 \%$ paraformaldehyde and $2.5 \%$ glutaraldehyde in $0.1 \mathrm{M}$ sodium cacodylate buffer $(\mathrm{pH} 7.2)$ for 4 $\mathrm{h}$ at room temperature. After fixation, fragments were post-fixed in $1 \%$ osmium tetroxide, $0.8 \%$ potassium ferricyanide and $5 \mathrm{mM}$ calcium chloride in $0.1 \mathrm{M}$ sodium cacodylate buffer for $1 \mathrm{~h}$. Subsequently, the samples were dehydrated through a gradient of acetone solutions and the tissues were embedded in Spurr. Semi thin sections $(3 \mu \mathrm{m})$ were cut on an ultramicrotome (Reichert Supernova, Heidelberg, Germany) for light microscopy studies and stained with toluidine blue. The ultra-thin sections (60-70nm) were contrasted with uranyl acetate and lead citrate, and examined under a Jeol 1011 (Jeol, Tokyo, Japan) transmission electron microscope. Parameters such as density and integrity of ooplasmic and granulosa cell organelles, vacuolization and basement membrane integrity were evaluated.

Statistical analysis. Means of surviving follicles at all stages, primordial and developing (primary or secondary) obtained after 1 or 7 days in the various treatments were subjected to analysis of variance (ANOVA) using GLM procedure of SAS (1999) and Dunnett's test applied to compare BMP-7 treated groups against control and $\mathrm{MEM}^{+}$. The $t$-student was used to compare differences among BMP-7 concentrations (Steel et al. 1997) and to compare means between 1 and 7 days of culture. Diameter of oocytes and follicles in the various treatments were subjected to analysis of variance (ANOVA) followed by SNK. Differences were considered to be significant when $\mathrm{P}<0.05$ and data were expressed as mean \pm standard error of means (SEM).

\section{RESULTS}

\section{Effect of BMP-7 on follicle survival}

In the present study, a total of 1,650 preantral follicles were analyzed. Primordial follicles were the most abundant type found in non-cultured ovarian tissue (fresh control, Fig. 1). Figure 2 shows the effect of different concentrations of BMP-7 on the follicular survival, i.e. the percentage of morphologically normal follicles in the fresh control and after 1 or 7 days of culture in caprine ovarian tissue. When the comparisons were done in the same culture period, it was verified that only the medium supplemented with $1 \mathrm{ng} /$ $\mathrm{ml}$ of BMP-7 after 1 day of culture maintained follicular survival similar $(P>0.05)$ to the observed in fresh control (non-cultured tissue). The other treatments significantly reduced $(P<0.05)$ the percentage of morphologically normal follicles after 1 or 7 days of in vitro culture compared with fresh control. Nevertheless, addition of BMP-7 to the

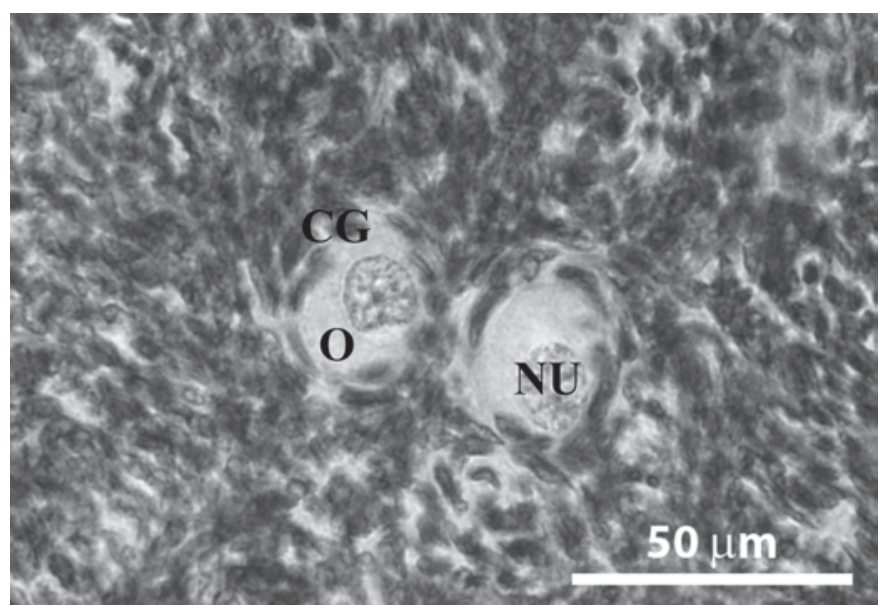

Fig.1. Histological section of non-cultured tissue after staining with periodic acid Schiff-hematoxylin, showing normal follicles. $\mathrm{O}=$ oocyte, $\mathrm{NU}=$ oocyte nucleus, $\mathrm{GC}=$ granulosa cells (400x). The scale bar represents $50 \mu \mathrm{m}$.

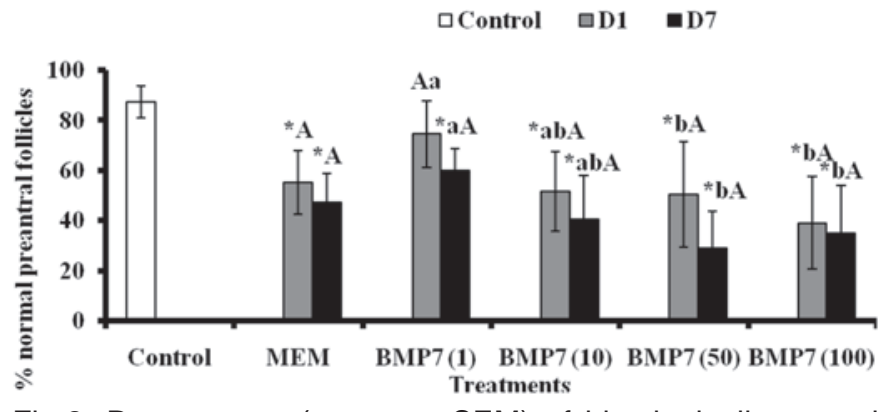

Fig.2. Percentages (means \pm SEM) of histologically normal preantral follicles in non-cultured tissue (control) and in tissue cultured for 1 and 7 days in $\mathrm{MEM}^{+}$and $\mathrm{MEM}^{+}$supplemented with $1,10,50$ and $100 \mathrm{ng} / \mathrm{ml} \mathrm{BMP-7.}{ }^{*} \mathrm{P}<0.05$, significantly different from non-cultured ovarian cortex tissue (control/D0). $(a, b)$ Different letters denote significant differences among treatments in the same period $(P<0.05) . A, B=$ Different letters denote significant differences between culture periods within the same medium $(\mathrm{P}<0.05)$.

medium did not show significant differences in the percentage of normal follicles when compared with $\mathrm{MEM}^{+}$ alone in both culture periods $(P>0.05)$. Comparisons done among the treatments with different concentrations of BMP7 , after 1 or 7 days of culture, showed that only the concentration of $1 \mathrm{ng} / \mathrm{ml}$ significantly increases $(P<0,05)$ the percentage of normal follicles compared with the others treatments. However, at both culture periods, this concentration of BMP-7 $(1 \mathrm{ng} / \mathrm{ml})$ did not differ the treatment in which culture medium had been supplemented with 10ng/ ml BMP-7.

\section{Goat primordial follicle activation and growth during in vitro culture}

The percentages of primordial and growing follicles in non-cultured cortex were $77.6 \%$ and $22.4 \%$, respectively (Table 1). In all treatments, after one or seven days of culture, there was no significant effect of BMP-7 in the 
Table 1. Percentages (mean \pm SEM) of primordial and growing follicles (primary and secondary) in non-cultured tissues and in tissues cultured for 1 or 7 days in $\mathrm{MEM}^{+}$(control medium) and $\mathrm{MEM}^{+}$supplemented with various concentrations of BMP-7

\begin{tabular}{ccccc}
\hline Treatments & \multicolumn{2}{c}{ Primordial follicles } & \multicolumn{2}{c}{ Growing follicles } \\
\hline Non-cultured (Day 0) & \multicolumn{2}{c}{$77.6 \pm 25.1$} & \multicolumn{2}{c}{$22.4 \pm 25.1$} \\
\hline Cultured & Day 1 & Day 7 & Day 1 & Day 7 \\
\hline MEM $^{+}$ & $83.3 \pm 19.6^{\mathrm{A}}$ & $57.3 \pm 26.6^{\mathrm{A}}$ & $16.7 \pm 19.6^{\mathrm{A}}$ & $42.7 \pm 26.6^{\mathrm{A}}$ \\
BMP-7 (1) $_{\text {BMP-7 (10) }}$ & $75.5 \pm 13.0^{\mathrm{a}, \mathrm{A}}$ & $59.6 \pm 23.4^{\mathrm{a}, \mathrm{A}}$ & $24.5 \pm 13.0^{\mathrm{a} A}$ & $40.4 \pm 23.4^{\mathrm{a}, \mathrm{A}}$ \\
BMP $^{\mathrm{a}, \mathrm{A}}$ & $64.1 \pm 31.0^{\mathrm{a}, \mathrm{A}}$ & $17.8 \pm 11.4^{\mathrm{a}, \mathrm{A}}$ & $35.9 \pm 31.0^{\mathrm{a}, \mathrm{A}}$ \\
BMP-7 (50) & $66.4 \pm 13.2^{\mathrm{a}, \mathrm{A}}$ & $69.4 \pm 19.5^{\mathrm{a}, \mathrm{A}}$ & $33.6 \pm 13.2^{\mathrm{a}, \mathrm{A}}$ & $30.6 \pm 19.5^{\mathrm{a}, \mathrm{A}}$ \\
BMP-7 (100) & $74.1 \pm 14.1^{\mathrm{a}, \mathrm{A}}$ & $57.8 \pm 12.7^{\mathrm{a}, \mathrm{A}}$ & $25.9 \pm 14.1^{\mathrm{a}, \mathrm{A}}$ & $42.2 \pm 12.7^{\mathrm{a}, \mathrm{A}}$
\end{tabular}

$\mathrm{a}, \mathrm{b}=$ Different letters in the same column denote significant differences among treatments in the same period $(P<0.05)$.

$A, B=$ Different letters in the same row denote significant differences between culture periods within the same medium $(\mathrm{P}<0.05)$.

Table 2. Follicle and oocyte diameters (mean \pm S.E.M.) in non-cultured tissues and in tissues cultured for 1 or 7 days in $\mathrm{MEM}^{+}$(control medium) and $\mathrm{MEM}^{+}$supplemented with various concentrations of BMP-7

\begin{tabular}{ccccc}
\hline Treatments & \multicolumn{2}{c}{ Follicle diameter $(\mu \mathrm{m})$} & \multicolumn{2}{c}{ Oocyte diameter $(\mu \mathrm{m})$} \\
\hline Non-cultured (Day 0) & \multicolumn{2}{c}{$30.1 \pm 4.4$} & \multicolumn{2}{c}{$23.7 \pm 2.6$} \\
\hline Cultured & Day 1 & Day 7 & Day 1 & Day 7 \\
\hline MEM $^{+}$ & $30.1 \pm 3.6^{\mathrm{A}}$ & $32.0 \pm 5.2^{\mathrm{B}}$ & $22.4 \pm 2.3^{\mathrm{A}}$ & $22.9 \pm 3.2^{\mathrm{A}}$ \\
BMP-7 (1) $^{\mathrm{a}}$ & $29.0 \pm 3.5^{\mathrm{a}, \mathrm{A}}$ & $33.2 \pm 3.7^{\mathrm{a}, \mathrm{A}}$ & $24.0 \pm 2.1^{\mathrm{a}, \mathrm{A}}$ & $24.5 \pm 3.0^{\mathrm{a}, \mathrm{A}}$ \\
BMP-7 (10) & $31.0 \pm 3.3^{\mathrm{a}, \mathrm{A}}$ & $33.8 \pm 4.1^{\mathrm{a}, \mathrm{B}}$ & $22.8 \pm 2.4^{\mathrm{a}, \mathrm{A}}$ & $24.0 \pm 2.0^{\mathrm{a}, \mathrm{A}}$ \\
BMP-7 (50) & $31.3 \pm 3.3^{\mathrm{a}, \mathrm{A}}$ & $30.7 \pm 4.2^{\mathrm{a}, \mathrm{A}}$ & $23.5 \pm 2.4^{\mathrm{a}, \mathrm{A}}$ & $23.0 \pm 2.7^{\mathrm{a}, \mathrm{A}}$ \\
BMP-7 (100) & $31.8 \pm 2.4^{\mathrm{a}, \mathrm{A}}$ & $32.9 \pm 6.4^{\mathrm{a}, \mathrm{A}}$ & $24.0 \pm 1.1^{\mathrm{a}, \mathrm{A}}$ & $24.9 \pm 3.5^{\mathrm{a}, \mathrm{A}}$
\end{tabular}

$\mathrm{a}, \mathrm{b}=$ Different letters in the same column denote significant differences among treatments in the same period $(\mathrm{P}<0.05)$.

$A, B=$ Different letters in the same row denote significant differences between culture periods within the same medium $(\mathrm{P}<0.05)$.

follicular activation, i.e., in the percentage of primordial and growing follicles $(P>0.05)$.

Follicular and oocyte diameter before and after in vitro culture were shown in Table 2. When the ovarian tissue was cultured only in $\mathrm{MEM}^{+}$or added with $10 \mathrm{ng} / \mathrm{ml}$ of BMP7 , it was observed a significant increase in follicular diameter from day 1 to $7(P<0.05)$. However, no significant differences were observed among the treatments, as well
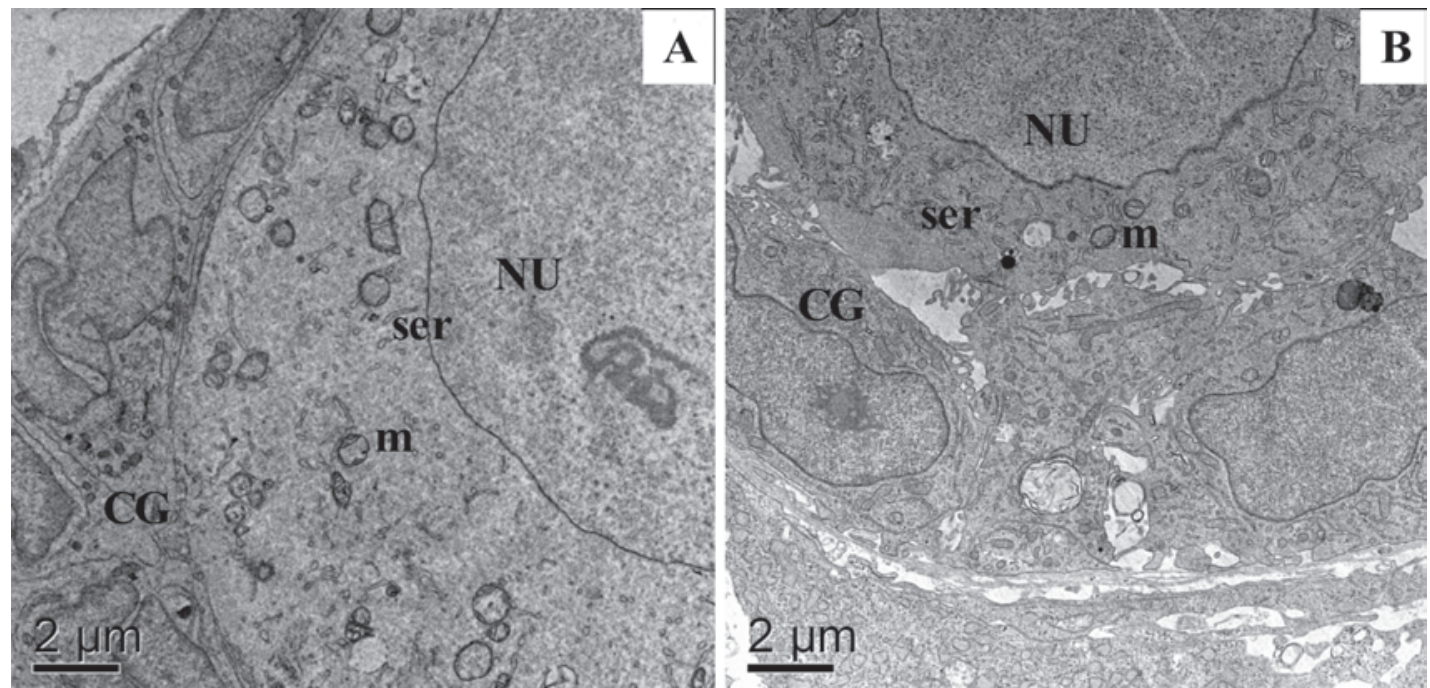

Fig.3. Transmission electromicrograph of a preantral follicle from (A) as a non-cultured control (7800x) and (B) cultured in BMP-7 $(1 \mathrm{ng} / \mathrm{ml})$ for 7 days $(1800 \mathrm{x})$. Note the homogeneous cytoplasm with numerous rounded mitochondria. $\mathrm{NU}=$ oocyte nucleus, $\mathrm{GC}=$ granulosa cells, $\mathrm{m}=$ mitochondria, ser $=$ smooth endoplasmic reticulum, $v=$ vesicle. The scale bar represents $2 \mu \mathrm{m}$. 
as when compared with fresh control $(P>0.05)$. Regarding oocyte diameter, we did not observe any influence of BMP7 in both culture periods $(P>0.05)$.

\section{Ultrastructural analysis of goat preantral follicles}

For better evaluation of follicular quality, ultrastructural analysis was performed using morphologically normal preantral follicles from fresh control, as well as from treatments that did not differ from control after 1 or 7 days of culture according to previous histological analysis (tissues cultured in BMP-7 at $1 \mathrm{ng} / \mathrm{ml}$ ). Figures $3 \mathrm{~A}$ and $3 \mathrm{~B}$ showed normal follicles observed in fresh control and after 7 days of culture in $1 \mathrm{ng} / \mathrm{ml}$ of BMP-7, respectively. In these follicles, it was cleared observed the presence of some vacuoles and several cytoplasmic organelles (especially, mitochondrion and endoplasmic reticulum) without degeneration signs, as well as the integrity of basal and nuclear membranes.

\section{DISCUSSION}

In the present study, it was demonstrated the importance of BMP-7 in the in vitro survival of caprine preantral follicles cultured for 7 days. The concentrations of BMP-7 used in this experiment $(1,10,50$ and $100 \mathrm{ng} / \mathrm{ml})$ were based on physiological concentrations of BMP-7 in rat ovaries (Shimasaki et al. 1999), as well as in studies with the direct injection of BMP-7 in the ovarian burse (Lee et al. 2001) and in vitro culture of mouse ovaries (Lee et al. 2004).

It was observed that follicles cultured for 1 day in the presence of $1 \mathrm{ng} / \mathrm{ml}$ of BMP-7 maintained the viability similar to that observed in non-cultured follicles (fresh control). Nevertheless, the other concentrations of BMP-7 significantly reduced the percentage of morphologically normal follicles compared with fresh control, except at $10 \mathrm{ng} / \mathrm{ml}$, which results did not differ from any other concentrations tested in the present study. In rats, BMP-7 and BMP-15 stimulated DNA synthesis by granulosa cells of primary follicles in vitro cultured. However, only BMP-7 maintained this stimulus when the granulosa cells were cultured together with the oocytes (Otsuka \& Shimasaki 2002). According to Dooley et al. (2000), BMPs are likely to play an autocrine and paracrine effect by granulosa and theca cells, respectively. In addition, BMP-6 and BMP-7 increase the secretion of FSH in the pituitary cells (Huang et al. 2001). Similar results to ours were observed by LEE et al. (2004), which cultivated mouse ovaries with BMP-7 and maintained follicular viability up to day 4 of culture.

Evaluating the effect of BMP-7 on the follicular activation and growth, it was observed that this substance did not affect the number of developing follicles in goats. Although BMP-7 did not promote follicular and oocyte growth in both culture periods, $\mathrm{MEM}^{+}$and BMP-7 at 10ng/ $\mathrm{ml}$ increase follicular diameter from day 1 ot 7 , which was not observed in oocyte diameter. Considering that previous studies (Silva et al. 2004a) did not evaluate protein expression of BMP receptors in goats, it can be suggested that either BMP-7 is not required for primordial follicle growth or mRNA for BMP receptors (Silva et al. 2004a) are not translated into protein by goat primordial follicles. Nevertheless, Lee et al. (2001) demonstrated in vivo, that direct injection of BMP-7 in the mouse ovarian burse leads to an increase in the number of developing follicles, reducing the number of primordial ones. These contradictory results can be explained by differences among species and protocols tested. Recently, in vitro studies showed that $100 \mathrm{ng} / \mathrm{ml}$ of BMP-7, in the presence of $\mathrm{FSH}$, promoted the transition from primordial to primary follicles in mouse, suggesting that BMP-7 can play a role in follicular activation when associated with FSH (Lee et al. 2004).

Our results regarding to the percentage of normal follicular morphology were confirmed by ultrastructural analysis. After TEM, it was observed that besides basal and nuclear membranes, important structures such as mitochondrias, endoplasmic reticulum and granulosa cells were preserved even after 7 days of culture in the presence of $1 \mathrm{ng} / \mathrm{ml}$ of BMP-7. Similar results were described previuosly after in vitro culture of caprine preantral follicles for 7 days in medium containing FSH (Matos et al. 2007a). However, the later authors showed that caprine follicles cultured in medium without adittion of $\mathrm{FSH}$ (control) presented ultrastructural alterations.

It is concluded that BMP-7, at the concentration of $1 \mathrm{ng} /$ $\mathrm{ml}$, maintains the survival and ultrastructure of preantral follicles after 7 days of caprine ovarian tissue culture.

Acknowledgments.- To Isabel B. Lima-Verde, Khesller P.O. Name, Cláudio C. Campello, and Liliam M.T. Tavares. This study was supported by grants from CNPq, CAPES, Fundação Cearense de Apoio à Pesquisa (Funcap) and International Foundation for Science (IFS). Valdevane $R$. Araújo is a recipient of a grant from CAPES (Brazil). The authors also thank Ms. J.B. Bruno, Ms. R.N. Chaves and Dr. M.H.T. Matos for his advice in editing the manuscript.

\section{REFERENCES}

Chaves R.N., Martins F.S., Saraiva M.V.A., Celestino J.J.H., Lopes C.A.P., Correia J.C., Lima-Verde I.B., Matos M.H.T., Báo S.N., Name K.P.O., Campello C.C., Silva J.R.V. \& Figueiredo J.R. 2008. Chilling ovarian fragments during transportation improves viability and growth of goat preantral follicles cultured in vitro. Reprod. Fertil. Dev. 20:640-647.

Danforth D.R., Arbogast L.K., Ghosh S., Dickerman A., Rofagha R. \& Friedman C.I., 2003. Vascular endothelial growth factor stimulates preantral follicle growth in the rat ovary. Biol. Reprod. 68:1736-1741.

Dooley C.A., Attia G.R., Rainey W.E., Moore D.R. \& Carr R. 2000. Bone morphogenetic protein inhibits ovarian androgen production. J. Clin. Endocrinol. Metab. 85:3331-3337.

Dube J.L., Wang P., Elvin J., Lyons K.M., Celeste A.J. \& Matzuk M.M. 1998. The bone morphogenetic protein 15 gene is X-linked and expressed in oocytes. Mol. Endocrinol. 12:1809-1817.

Glister C., Kemp C.F. \& Knight P.G. 2004. Bone morphogenetic protein (BMP) ligands and receptors in bovine ovarian follicle cells: actions of BMP-4, -6 and -7 on granulosa cells and differential modulation of Smad-1 phosphorylation by follistatin. Reproduction 127:239-254.

Gougeon A. 1996. Regulation of ovarian follicular development in primates: Facts and hypotheses. Endocr. Rev. 17:121-155.

Hogan B.L. 1996. Bone morphogenetic proteins: Multifunctional regulators of vertebrate development. Genes and Development 10:1580-1594. 
Huang H.-J., Wu J.C., Su P., Zhirnov O. \& Miller W.L. 2001. A novel role for morphogenetic proteins in the synthesis of Follicle-Stimulating Hormone. Endocrinology 142:2275-2283.

Hulshof C.J., Figueiredo J.R., Beckers J.F., Bevers M.M. \& Van Den Hurk R. 1994. Isolation and characterization of preantral follicles from foetal bovine ovaries. Vet. Quart. 16:78-80.

Lee W-S., Otsuka F., Moore R.K. \& Shimasaki S. 2001. Effect of bone morphogenetic protein-7 on folliculogenesis and ovulation in the rat. Biol. Reprod. 65:994-999.

Lee W-S., Yoon S-J., Yoon T-K., Cha K-Y., Lee S-H., Shimasaki S., Lee S. \& Lee K-A. 2004. Effects of bone morphogenetic protein-7 (BMP-7) on primordial follicular growth in the mouse ovary. Mol. Reprod. Dev. 69:159-163.

Matos M.H.T., Lima-Verde I.B., Luque M.C.A., Maia Jr J.E., Silva J.R.V., Celestino J.J.H., Martins F.S., Báo S.N., Lucci C.M. \& Figueiredo J.R. 2007a. Essential role of follicle stimulating hormone in the maintenance of caprine preantral follicle viability in vitro. Zygote 15:173-182.

Matos M.H.T., Lima-Verde I.B., Bruno J.B., Lopes, C.A.P., Martins F.S., Santos K.D.B., Rocha R.M.P., Silva J.R.V., Báo S.N. \& Figueiredo J.R. 2007b. Follicle stimulating hormone and fibroblast growth factor2 interact and promote goat primordial follicle development in vitro. Reprod. Fertil. Dev. 19:677-684.

Otsuka F. \& Shimasaki S. 2002. A negative feedback system between oocyte bone orphoenetic protein 15 and granulosa cell kit ligand: Its role in regulation cell mitosis. Proc. Natl Acad. Sci. 11:80608065.

Quinn R.L., Shuttleworth G. \& Hunter M.G. 2004. Immunohistochemical localization of the bone morphogenetic protein receptors in the porcine ovary. J. Anat. 205:15-23.

Steel R.G.D., Torrie J.H. \& Dickey D. 1997. Principles and procedures of statistics: A biometrical approach. $3^{\text {rd }}$ ed. McGraw-Hill, New York.

Shimasaki S., Zachow R.J., Li D., Kim H., lemura S-I., Ueno N., Sampath K., Chang R.J. \& Erickson G.F. 1999. A functional bone morphogenetic protein system in the ovary. Proc. Natl Acad. Sci. 96:7282-7287.

Silva J.R.V., Van den Hurk R., van Tol H.T.A., Roelen B.A.J. \& Figueiredo J.R. 2004a. Expression of growth differentiation factor 9 (GDF9), bone morphogenetic protein 15 (BMP15), and BMP receptors in the ovaries of goats. Genetics, Gene Regulation, and Expression. Mol. Reprod. Dev. 70:1-19.

Silva J.R.V., Van den Hurk R., Matos M.H.T., Santos R.R., Pessoa C., Moraed M.O. \& Figueiredo J.R. 2004b. Influences of FSH and EGF on primordial follicles during in vitro culture of caprine ovarian cortical tissue. Theriogenology 61:1691-1704.

Wozney J.M. \& Rosen V. 1998. Bone morphogenetic protein and bone morphogenetic protein gene family in bone formation and repair. Clin. Orthop. 346:26-37. 